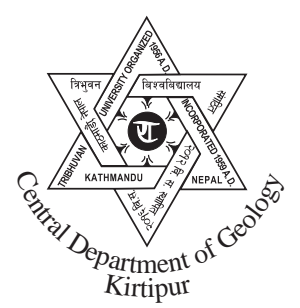

Bulletin of the D epartm entofG eology

\title{
Lithofacies and depositional environment of the Siwalik Group in Samari-Sukaura River area, Central Nepal
}

\author{
Dev Kumar Syangbo and *Naresh Kazi Tamrakar \\ Central Department of Geology, Tribhuvan University, Kathmandu, Nepal
}

\begin{abstract}
Thick sedimentary sequence deposited in the foreland basin of the Nepal Himalaya is represented by the Siwalik Group. The Siwalik Group is well exposed in the Samari-Sukaura River area. The present study is focused in southern portion of the MBT around the Samari-Sukaura area for its depositional environment. The Middle Siwaliks of the Sukaura Road sections is overlained by the Lower Siwaliks which is separated by the Karki Khola Thrust. Extension of the Lower Siwaliks in the Jyamire Khola and the Bundal Khola becomes wider in the eastern Zone. Repetition of the Lower Siwaliks along the southern margin of the MBT is recognized. Depending on lithofacies assemblage and facies analysis, the two broad facies assemblages FA1 and FA2 have been distinguished. FA1 shows SB, FF, LA, LS and CH architectural elements and is interpreted as a product of the fine-grained meandering river system. FA2 shows SB, FF, LA, DA and CH architectural elements and is interpreted as a product of sandy mixed-load meandering river system.
\end{abstract}

K ey w ords: Facies assemblage, facies analysis, graphic log, Lower Siwaliks, Middle Siwaliks, Nepal Sub-Himalaya

\section{IN TRODUCTIO N}

The Siwalik Group is tectonically bounded between the Main Boundary Thrust (MBT) in the north and the Main Frontal Thrust (MFT) in the south, and is separated from the Lesser Himalaya in the north and the Indo Gangatic Plain in the south. It is thick sedimentary sequence, which extends throughout the East-West of the southern belt of the Himalayas, and represents the youngest mountain belt of the Himalayas (Tokuoka et al., 1986; Tokuoka, 1992; Kizaki, 1994). It is the foreland basin of the Himalayas and has the deposit of sediments of the Middle Miocene to the Early Pleistocene time

*Corresponding author:

E-mail address: ntamrakar@hotmail.com
(Gautam and Rosler, 1999). This foreland basin was produced by the subsequent collision of the Indian and the Eurasian plates in Eocene time during the Himalayan orogeny, and the evidence of plate tectonics and upliftment of the Himalaya is seen in these Siwalik rocks(Tokuoka et al., 1986; Kizaki, 1994; Critelli and Ingersoll, 1994; DeCelles et al., 1998). About 6 km in thickness but thickness varies considerably from place to place depending upon various factor such as size of the basin, source of sediment (Chaudhari and Gill, 1981; Chaudhri, 1982; Critelli and Ingersoll, 1994; DeCelles et al., 1998; Tamrakar, 1998), and paleohydraulics (Ulak and Nakayama, 1999; Ulak, 2002). The Siwaliks of the Central Nepal have been worked out earlier for lithostratigraphy (Sah et al.,1994; Ulak and Nakayama, 


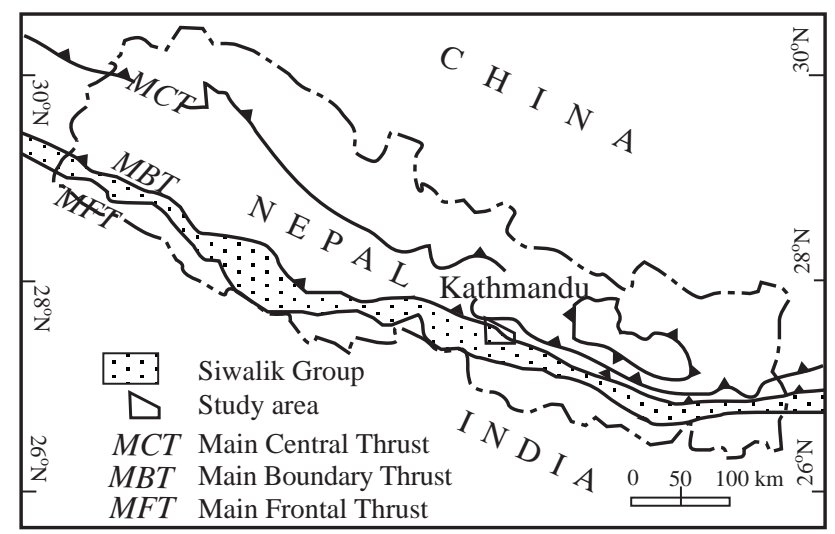

Fig. 1 Location of study area.

1998; Nakayama and Ulak,1999), lithofacies and paleohydraulics (Ulak, 2002), geomorphology (Kimura, 1995; Tamrakar and Khakurel, 2012), petrography and microfabrics (Tamrakar et al., 2000; Tamrakar, 2004), and provenance (Chaudhari and Gill, 1981; Chaudhri, 1982). Present study is focused on sedimentary lithofacies analysis using statistical tool and to indentify the depositional environments of the Siwalik Group distributed in the southern front of the Main Boundary Thrust (MBT) in Samari-Sukaura River area. The Siwalik Group in this area were largely undifferentiated, and were previously assigned to various litho-units by different authors, e.g., Amlekhganj Formation (Sah et al., 1994), Upper Member of the Amlekhganj Formation (Nakayama and Ulak,1999; Ulak, 2002), Lower Siwaliks by Petroleum exploration promotion project, (2002). Therefore, the present study attempts to differentiate the lithological units based on facies analysis.

\section{ETHODS}

In present study, sedimentary rocks formed by fluvial deposits are classified based on Miall (1978 and 1996). Statistical analysis, using Markov chain is the approach to test significance of vertical transition between strata. Selley's (1979) method of analysis along with the Harper's (1984) binomial probability method were followed in facies analysis. The significant transitions were traced out and the facies assemblages were related with the channel elements of Miall (1996) to deduce possible assemblages of elements of the river style and depositional environment.

\section{GEOLOG ICAL SETT ING}

Lithostratigraphy of the Amlekhganj-Hetauda was established by Sah et al. (1994) and that of the Bakiya Khola was studied by Ulak and Nakayama (1999). They separated the Siwaliks groups into the Rapti, Amlekhganj, Churia Khola and the Churia Mai Formations, in an ascending order, divided both the Rapti and the Amlekhganj Formations in to the Lower, Middle and the Upper Members. These complete four formation are only present in the southern belt of the Sub-Himalaya. In the northern belt, only the lower two formations are distributed and can not be differentiated into specified members in the study area due to contrasting lithological characteristics that are quite different from those of earlier workers. Therefore, the widely accepted three-fold division of the Siwalik Group, as were established by Auden (1935) who classified the Siwaliks based on lithology and increasing grain size into three units; the Lower, the Middle and the Upper Siwaliks, were used in the present study. The similar three-fold division of the Siwalik Group was also adopted by Petroleum exploration promotion project, (2002) .

The study area extends from Hetauda to Suparitar in the western portion and Shikharkateri to Sukaura in the eastern portion (Fig. 2). The first appeared southern hills of the Lower Siwaliks are overlain by the Middle Siwaliks, and is inturn overlain by the Lower Siwaliks showing a thrust contact, the Karki Khola Thrust. The Lower Siwaliks are exposed in the Bundal Khola, Majuwa Khola, Bhalu Khola, Samari Khola and Sukaura Road, and are thrusted over by the Lesser Himalayan unit along the Main Boundary Thrust. Usually, the Lesser Himalayan unit is composed of slate and limestone, but in the Sukaura Road section, the Lower Siwaliks are overlain by amphibolite and then white quartzite and slate of the Lesser Himalayan unit. Here, the strata are overturned to about 29 degrees. A shear zone of breciated to gouged lithology is observed between amphibolite and sandstone. In the river sections, a shear zone showing breciated to gouged lithology has thickness upto $50 \mathrm{~m}$, comprising crushed portion of Siwalik mudstone and fine-grained sandstone. At Khoplan, the shear zone composes only the breciated fragments of slates.

The southwestern portion of the area (Fig. 2) comprises of gravel deposit of the Dun Valley and are distinguished as the Quaternary Deposit. 

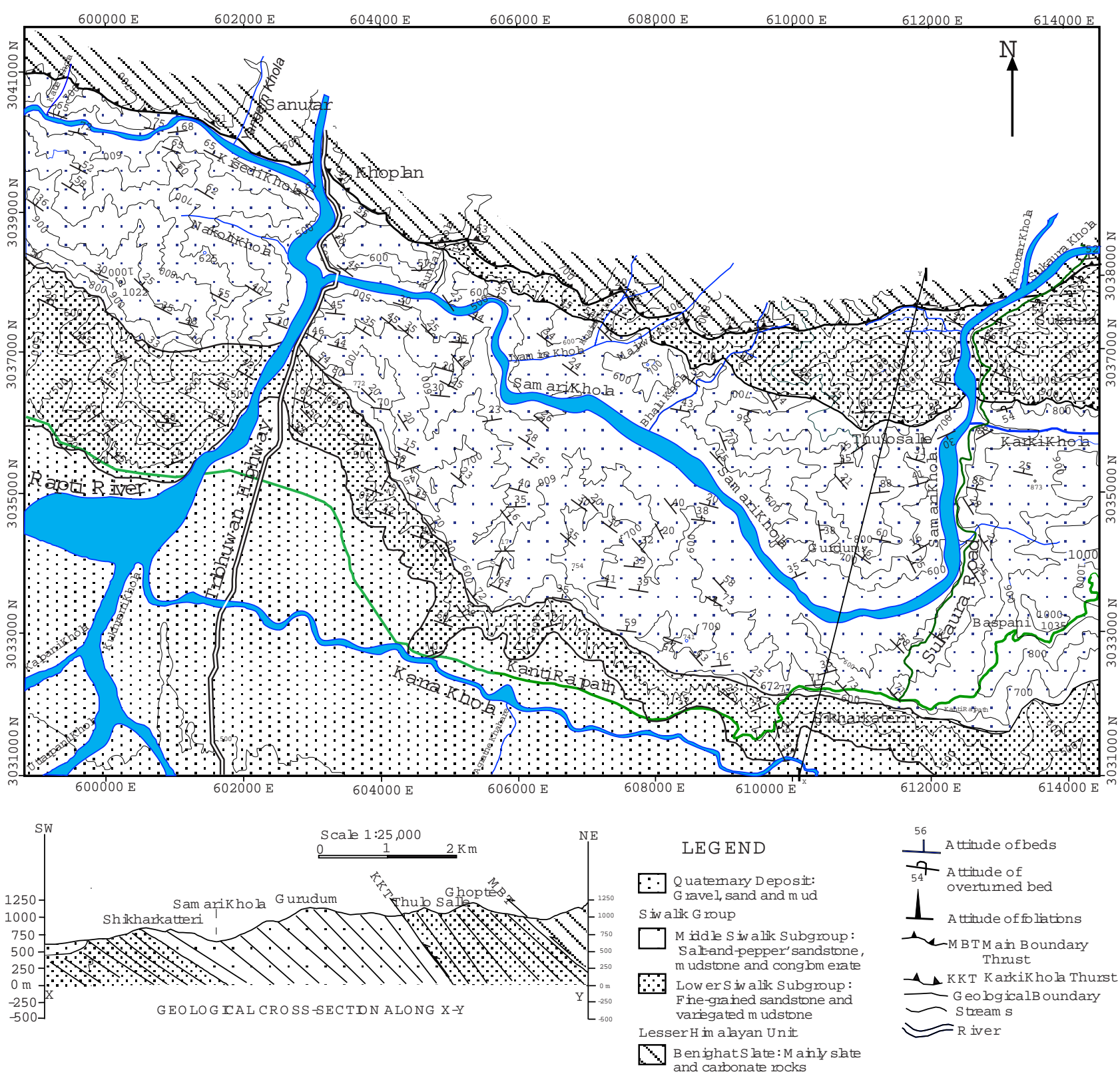

Fig. 2 Geological map and cross-section of the Samari-Sukaura Khola area, Central Nepal, Sub-Himalaya.

\section{L ow er Sİ aliks}

The Lower Siwaliks of the Sukaura Road section consists of the trough-cross bedded to ripple crosslaminated, fine-grained, greenish grey to brown sandstone interbedded with greenish grey to red purple mudstone. Planar cross bedded, highly calcareous fine- to very finegrained, greenish grey sandstone is dominant in this section near the MBT (Fig. 2). Spheroidally weathered, bioturbated, variegated, greenish grey to purple mudstone and shale with numerous fossils of the plant leaves and petrified wood fragments are present. Thickness of the sandstone beds of the Lower Siwaliks of the Baspani Sukaura road section varies from 0.2 to $7.0 \mathrm{~m}$, and thickness of the mudstone beds approaches up to $7 \mathrm{~m}$ (Fig. 3). Sandstone beds of the Lower Siwaliks in the Sukaura Road section near to the MBT are dipping towards the south and are overturned as exhibited by cross-beds.

The Lower Siwaliks are also exposed along the Bhalu Khola, where sandstones are rippled-laminated to planar cross-bedded, fine-grained, and greenish grey, and are interbedded with greenish grey to purple, and variegated 

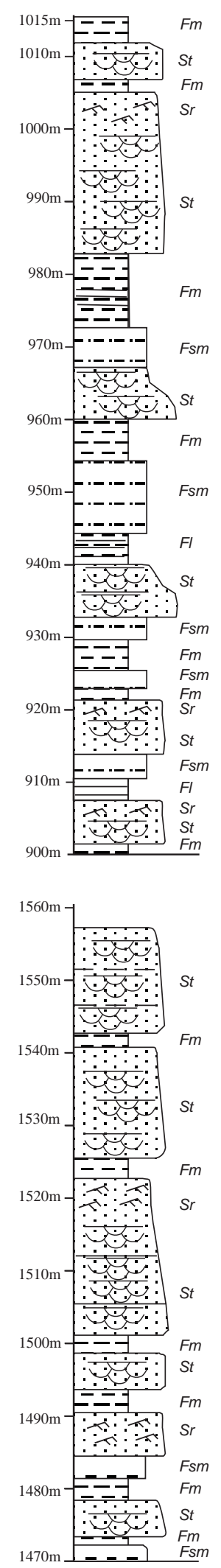

Greenish purple mudstone

Trough cross-bedded, f.-grained brn. grey sandstone Spheroidally weathered, greenish grey mudstone

Trough cross-bedded, f.-grained brn. grey sandstone

Spheroidally weathered, redish purple mudstone

Greenish grey claystone

Greenish grey siltstone

Tr. cross-bedded, med.- to f.-grained, grn. gr. sandstone

Greenish grey mudstone

Greenish grey siltstone

Greenish grey shale

Tr. cross-bedded, f.-grained grey to brown sandstone

Medium- to fine-grained, greenish grey sandstone Grey siltstone

Spheroidally weathered greenish grey mudstone Greenish grey siltstone

Grey mudstone

Tr. cross- to ripple laminated, grn. gr. f.-grained sandstone

Greenish grey siltstone

Purple shale

Ripple cross lam., med.- to f.-grained brn. gr. sandstone

Tr. cross-beddded, med.- to f.-grained, gr. sandstone

Greenish grey mudstone

Colluvium deposit

Very thick, trough cross- bedded, f.-grained br. sandstone

Greenish grey mudstone

Very thick, trough cross- bedded, f.-grained br. sandstone

Greenish grey mudstone

Rippled cross-laminated, fine-grained grey sandstone

Very thick, tr. cross- bedded, f.-grained gr. grey sandstone

Grey mudstone

Very thick, tr. cross- bedded, f.-grained gr. grey sandstone

Grey mudstone

Rippled cross-laminated, fine-grained grey sandstone

Greenish grey siltstone

Greenish grey mudstone

Thick, tr. cross- bedded, f.-grained grey sandstone

Greenish grey mudstone

Grey siltstone
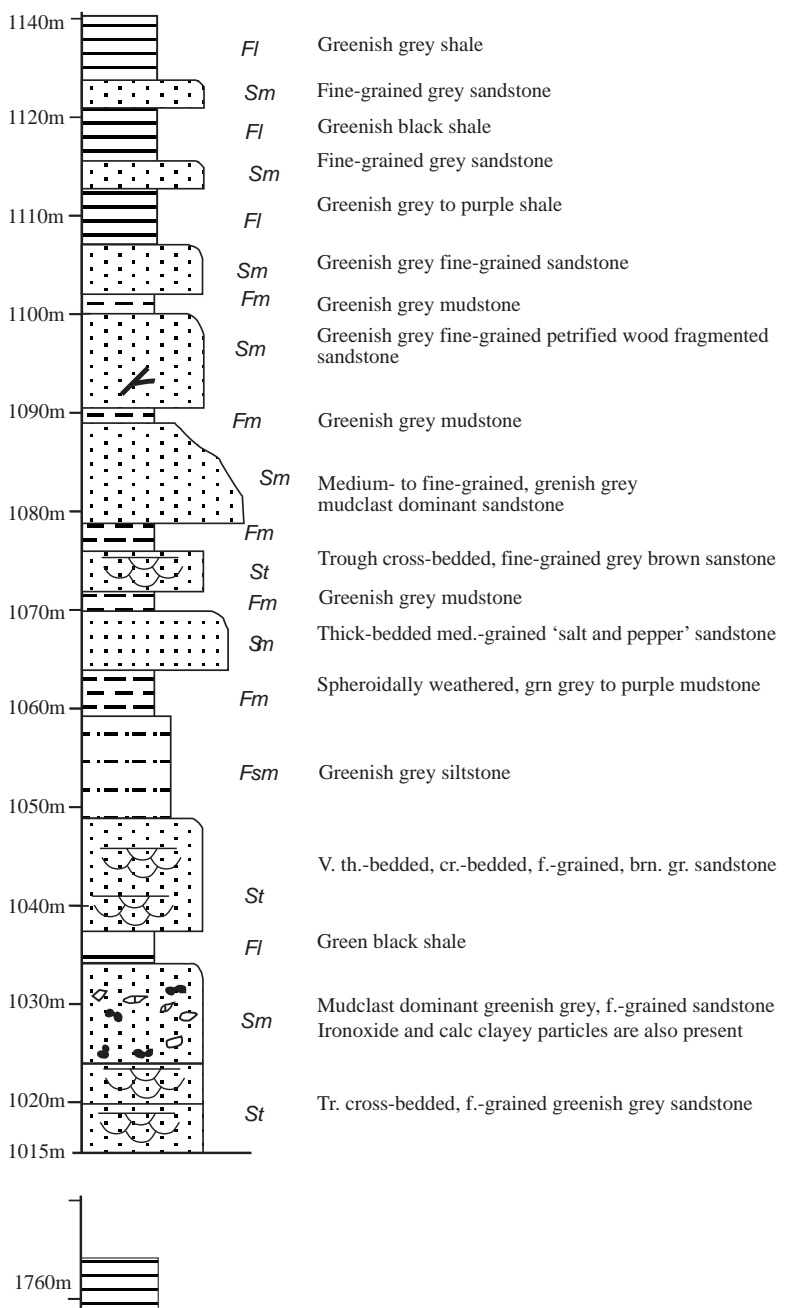

Black slate

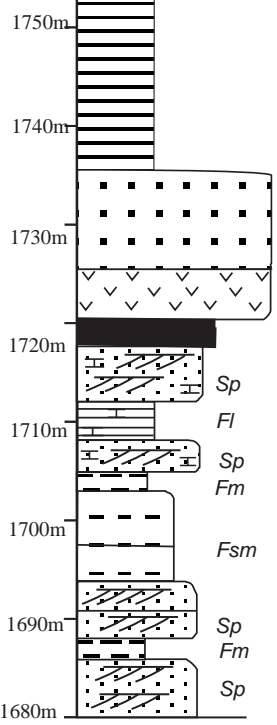

Thick-bedded, medium- to fine-grained white quartzite

Green amphibolite

Shear zone MBT

Planar cross-bedded, fine-grained, grey calcareous sandstone

Greenish grey calcareous claystone

Planar cross-bedded, f.-grained, grn. grey calc. sandstone Greenish grey mudstone

Thick-bedded, greenish grey weathered siltstone

Planar cross-bedded, f.-grained, grn grey sandstone

Red purple mudstone

Pl. cross-bedded, v. thick-bedded, f.-grained, light grey sandstone

Fig. 3 Distribution of the Sedimentary sequence of the Lower Siwaliks at Sukaura Road section. 

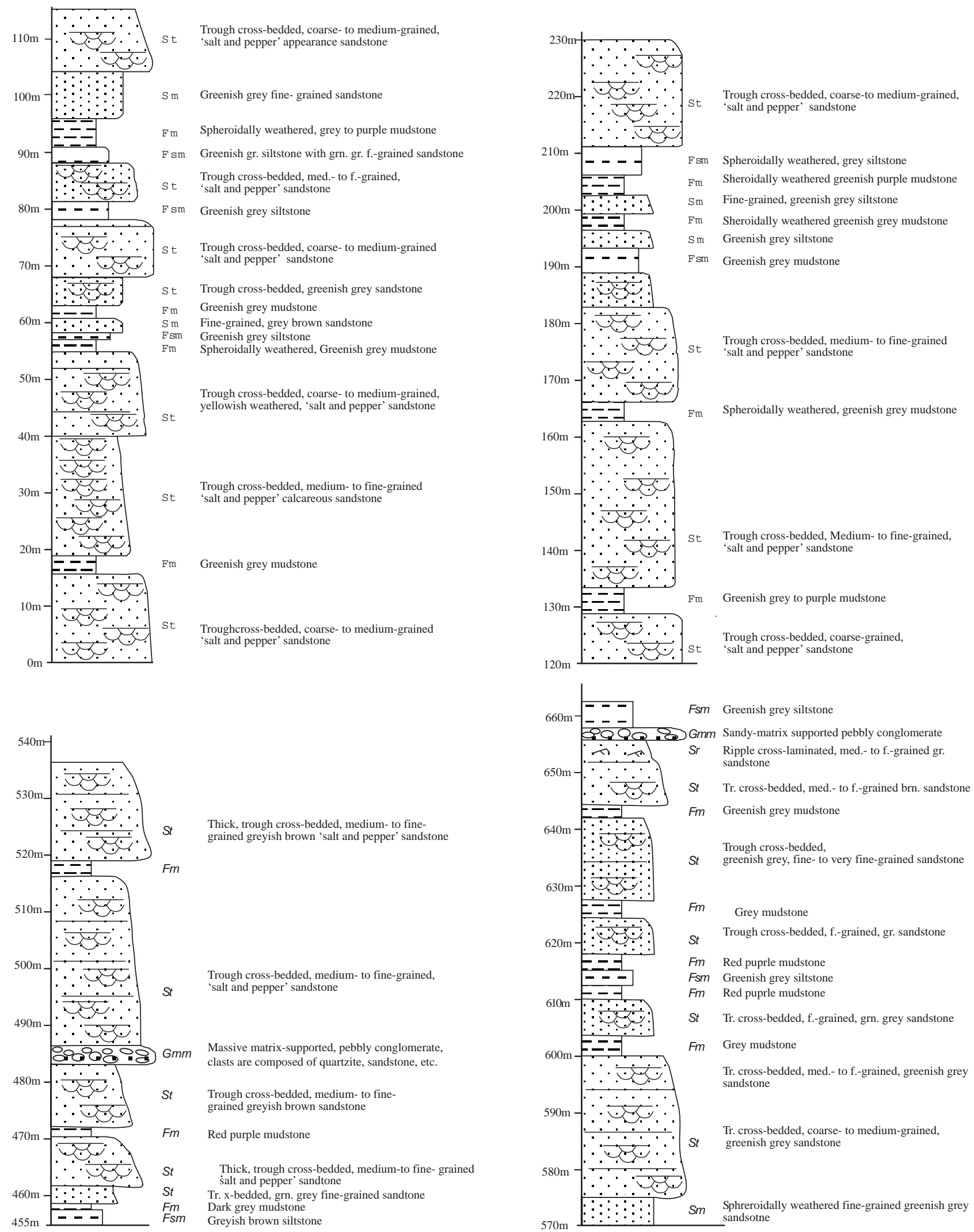

Fig. 4 Distribution of the Sedimentary sequence of the Middle Siwaliks at Sukaura Road section. 
mudstone. Similar lithologic characters are also exposed along the Jyamire Khola and the Bundal Khola near to the MBT.

\section{M iddle Siv aliks}

The Middle Siwaliks comprise of very coarse- to coarse-grained 'salt and pepper' sandstones. 'Salt and pepper' appearance is due to the presence of biotite, quartz and feldspar grains. Trough cross-bedded, ripple laminated, coarse to medium-grained, 'salt and pepper' sandstone beds are interbedded with greenish grey to brown, spheroidally weathered, and bioturbated mudstones, which are well exposed around the Sukaura road section. Thickness of the sandstone beds varies from 0.4 to $12 \mathrm{~m}$ (Fig. 4 ).

The Middle Siwaliks are also exposed along the Tribhuvan Highway, Hetauda-Suparitar area, Kisedi Khola, Bundal Khola, and Jyamire Khola sections, where they are characterized by pebbly, 'salt and pepper' sandstone. The matrix-supported, pebbly conglomerate beds having thickness of 3.5-5.5 $\mathrm{m}$ are found in this unit. In the Bhalu Khola, the Bundal Khola, the Kisedi Khola and the Jyamire Khola sections, matrix-supported, pebbly conglomerate beds subordinated with trough crossbedded, coarse to medium-grained, pebbly 'salt and pepper', and grey to brown sandstones are generally observed.

\section{FAC I S ANALSYSIS AND IN TERPRETATIO N}

Mainly three different types of lithofacies have been identified from the Sukaura Road section. Vertical lithostratigraphic column were established along the Sukaura Road section and Jyamire Khola section. Facies analysis for the Middle and Lower Siwalik succession was made separately. Entire lithostratigraphic column proceeded under facies analysis (Tables 1 to 6). Lithostratigraphic column of the Sukaura Road section proceeded for the facies analysis was coded based on classification of Miall $(1978,1996)$. The occurrence of the assemblage of the lithofacies were statistically analysed under the separate unit into the separate table and different facies relationship diagram (FRD) were generated. Binomial probability for facies transition having high positive values between observed and independent trial probability were choosen significance level of 0.10 then marked the significant transitions, i.e, significant level $10 \%$, and when $\mathrm{P}>0.10$ the transition is not significant. FRD shows transition that occurred commonly and significantly at $10 \%$ significant level than random. In FRD more significant transition are highlighted by dark solid arrows. Vertical and lateral changes of the fluvial deposits were also noticed around the study area. Each lithofacies reflects the depositional phenomenon of the Siwaliks of the study area.

Table 1: Transition count matrix of the Lower Siwaliks of the Samari-Sukaura area

\begin{tabular}{|c|c|c|c|c|c|c|c|c|c|c|}
\hline & $\mathrm{Gmm}$ & $\mathrm{St}$ & $\mathrm{Sm}$ & $\mathrm{Sr}$ & $\mathrm{Sp}$ & $\mathrm{Fm}$ & Fsm & $\mathrm{Fr}$ & $\mathrm{Fl}$ & \\
\hline $\mathrm{Gmm}$ & & & & & & & & & & 0 \\
\hline $\mathrm{St}$ & & & & 6 & 1 & 18 & 6 & & 6 & 37 \\
\hline $\mathrm{Sm}$ & & & & & & 4 & & & 3 & 7 \\
\hline $\mathrm{Sr}$ & & & & & & 6 & 2 & & 1 & 9 \\
\hline $\mathrm{Sp}$ & & & & 1 & & 3 & 2 & & & 6 \\
\hline Fm & & 29 & 4 & 1 & 5 & & 10 & & & 49 \\
\hline Fsm & & 1 & 1 & 1 & 2 & 15 & & & & 20 \\
\hline Fr & & & & & & & & & & 0 \\
\hline \multirow[t]{2}{*}{$\mathrm{Fl}$} & & 5 & & & & 2 & 2 & & & 9 \\
\hline & 0 & 30 & 5 & 9 & 8 & 48 & 22 & 0 & 10 & 128 \\
\hline
\end{tabular}

Table 2:Difference matrix of the Lower Siwaliks of the SamariSukaura area

\begin{tabular}{|c|c|c|c|c|c|c|c|}
\hline & $\mathrm{Gmm} \mathrm{St}$ & $\mathrm{Sm}$ & $\mathrm{Sr}$ & $\mathrm{Sp}$ & $\mathrm{Fm}$ & Fsm & $\begin{array}{ll}\mathrm{Fr} & \mathrm{Fl} \\
\end{array}$ \\
\hline \multicolumn{8}{|l|}{$\mathrm{Gmm}$} \\
\hline St & & & 0.102 & -0.049 & 0.091 & -0.031 & 0.092 \\
\hline $\mathrm{Sm}$ & & & & & 0.610 & & 0.669 \\
\hline $\mathrm{Sr}$ & & & & & 0.347 & 0.065 & 0.041 \\
\hline $\mathrm{Sp}$ & & & 0.092 & & 0.100 & 0.150 & \\
\hline $\mathrm{Fm}$ & 0.217 & 0.019 & -0.092 & 0.002 & & -0.071 & \\
\hline Fsm & -0.233 & 0.003 & -0.035 & 0.025 & 0.297 & & \\
\hline \multicolumn{8}{|l|}{ Fr } \\
\hline $\mathrm{Fl}$ & 0.301 & & & & -0.185 & 0.036 & \\
\hline
\end{tabular}

Table 3: Binomial probability for facies transitions of the Middle Siwaliks having high positive difference value between observed and independent trail probability

\begin{tabular}{lcccc}
\hline $\begin{array}{l}\text { Transition } \\
\text { i to j }\end{array}$ & $\begin{array}{l}\text { Transition } \\
\text { probability for } \\
\text { random sequence }\end{array}$ & $\mathrm{N}$ & $\mathrm{M}$ & $\begin{array}{c}* * * \text { Binomial } \\
\text { probability (P) }\end{array}$ \\
\hline *Sm to Fm & 0.390 & 7 & 4 & 0.271 \\
*Sm to Fl & 0.081 & 7 & 3 & 0.020 \\
*Sr to Fm & 0.403 & 9 & 6 & 0.103 \\
*Fsm to Fm & 0.453 & 20 & 15 & 0.007 \\
*Fm to St & 0.592 & 49 & 29 & 0.459 \\
*Fl to St & 0.556 & 9 & 5 & 0.631 \\
$* *$ St to Sr & 0.194 & 6 & 2 & 0.750 \\
$* *$ Sp to Fsm & 0.333 & 37 & 6 & 0.648 \\
\hline
\end{tabular}

*Transition having value $>0.20$ in difference matrix

** Transition having value $>0.10<0.20$ in difference matrix $* * * \mathrm{P}<0.10$ is significant

$\mathrm{N}=$ Total number of $\mathrm{i}$ in a rwo in a transition count matrix;

$\mathrm{M}=$ Total number of transition from $\mathrm{i}$ to $\mathrm{j}$ in a transition count matrix 
Table 4: Transition count matrix of the Middle Siwaliks of the Samari-Sukaura area

\begin{tabular}{lcccccccc}
\hline & Gmm & St & Sm & Sr & Fm & Fsm & Fr & \\
\hline Gmm & & 1 & & & & 1 & & 2 \\
St & 1 & & & 4 & 19 & 7 & 2 & 33 \\
Sm & & 2 & & & 4 & & & 6 \\
Sr & 1 & 1 & & & 1 & 1 & & 4 \\
Fm & & 23 & & & & 7 & & 30 \\
Fsm & & 6 & 3 & & 8 & & & 17 \\
Fr & & 1 & & & & 1 & & 2 \\
& 2 & 34 & 3 & 4 & 32 & 17 & 2 & 94 \\
\hline
\end{tabular}

Table 5: Difference matrix of the Middle Siwaliks of the SamariSukaura area

\begin{tabular}{lccccccc}
\hline & $\mathrm{Gmm}$ & $\mathrm{St}$ & $\mathrm{Sm}$ & $\mathrm{Sr}$ & $\mathrm{Fm}$ & Fsm & Fr \\
\hline $\mathrm{Gmm}$ & & 0.130 & & & & 0.315 & \\
$\mathrm{St}$ & -0.003 & & & 0.055 & 0.042 & -0.071 & 0.027 \\
$\mathrm{Sm}$ & & -0.040 & & & 0.315 & & \\
$\mathrm{Sr}$ & 0.228 & -0.128 & & & -0.106 & 0.061 & \\
$\mathrm{Fm}$ & & 0.218 & & & & -0.041 & \\
Fsm & & -0.089 & 0.138 & & 0.055 & & \\
Fr & & 0.130 & & & & 0.315 & \\
\hline
\end{tabular}

Table 6: Binomial probability for facies transitions of the Lower Siwaliks having high positive difference value between observed and independent trail probability

\begin{tabular}{lcccc}
\hline Transition i to j & $\begin{array}{l}\text { Transition } \\
\text { probability for } \\
\text { random sequence }\end{array}$ & $\mathrm{N}$ & $\mathrm{M}$ & $\begin{array}{c}* * * \text { Binomial } \\
\text { probability (P) }\end{array}$ \\
\hline *Sm to Fm & 0.352 & 6 & 4 & 0.120 \\
*Gmm to Fsm & 0.185 & 2 & 1 & 0.336 \\
*Fr to Fsm & 0.185 & 2 & 1 & 0.336 \\
*Sr to Gmm & 0.022 & 4 & 1 & 0.085 \\
*Fm to St & 0.548 & 30 & 23 & 0.008 \\
**Gmm to St & 0.370 & 2 & 1 & 0.603 \\
*Fr to St & 0.370 & 2 & 1 & 0.603 \\
**Fsm to Sm & 0.039 & 17 & 3 & 0.027 \\
\hline
\end{tabular}

*Transition having value $>0.20$ in difference matrix

** Transition having value $>0.10<0.20$ in difference matrix

$* * * \mathrm{P}<0.10$ is significant

$\mathrm{N}=$ Total number of $\mathrm{i}$ in a rwo in a transition count matrix

$\mathrm{M}=$ Total number of transition from $\mathrm{i}$ to $\mathrm{j}$ in a transition count matrix

\section{$\mathrm{C}$ onglom erate $\mathrm{F}$ acies}

Sandy matrix supported pebbly conglomerate is recognized in the Middle Siwaliks. It is $2-3 \mathrm{~m}$ thick fluvial deposits which is composed of the clast of the quartzite, meta sandstone, sandstone, phyllite (Fig. 5). The diameter of the clasts ranges from 2.5 to $6 \mathrm{~cm}$. Distribution of conglomerate is absence in the Lower Siwalik rock units of the Baspani- Suakaura road section.

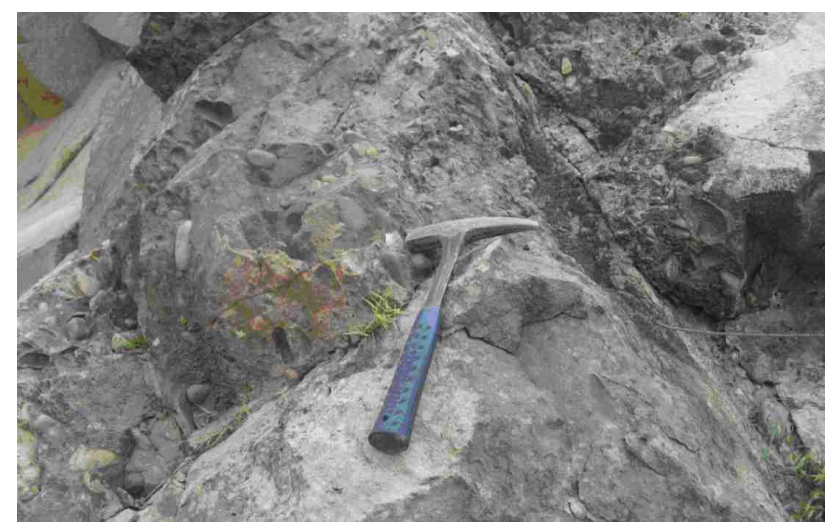

Fig. 5 Photograph showing lithofacies; Channel lag deposits at the Middle Siwaliks along the Sukaura Road section

Vertically, difference probability transition exists with Fm and St facies of this upward transitions. This facies is laterally extended. Facies Gmm to St and Fsm have positive values indicating that these types of facies associations have occurred meaningfully (Fig. 4). Lithofacies Gmm shows matrix-supported massive gravel having weak grading. This lithofacies indicates that deposition of the beds occured by the high strength debris flow (Miall, 1996). Flow may have occupied the preexisting channel and had channelized forms as channel lag deposits.

\section{Sandstone Facies}

Sandstone facies results from transport of sand by traction current as bed load and intermittent suspension or saltation. The resulting bedforms produced in sand depends on velocity, flow depth and grain size of the sand and also other parameters such as fluid viscosity (Miall 1978; Miall 1996).

\section{Trough C ross bedded Sandstone, St}

In the Sukaura road section, from Baspani to Karki Khola, trough cross-bedded, medium- to fine-grained, 'salt and pepper' sandstone occurs predominantly (Figs. 2 and 4) whereas between Karki Khola and Sukara in the Sukaura road section, lithofacies mainly dominated by trough cross-bedded, fine- to very fine-grained, greenish grey to brown sandstone.

In the Lower Siwaliks of the study area, St facies is well associated with $\mathrm{Fm}$, and $\mathrm{Fl}$ also transitioned into $\mathrm{Sr}$, Sp, Fsm. St facies occurs more frequently and follows $\mathrm{Fm}$ and $\mathrm{Fl}$ facies (Fig. 6). This facies indicates that trough cross-bedded sandstones produced by migration of 3-D 
dunes in the channel is often followed by lithofacies produced at in floodplain, showing slow lateral migration of channel. Cross bedding is curved at the base of the trough which shows erosional relationship with the underlying bedforms.

Vertically, St facies is well associated with Fm and Fsm facies in the Middle Siwaliks. St is also occasionally followed by Sr, Fr, and Gmm facies (Fig. 4). St into Sr, $\mathrm{Fm}$, Fr having positive values indicates that these types of the facies have occurred more frequently in the Middle Siwaliks of the Sukauara Road section, and the significant transitions from Sr to St, Fm to St and Gmm to St (Fig. 7), indicate flooding events frequently carrying sands and occasionally gravels which are overlain by trough cross-bedded traction current generated bedforms. Transition from ripple cross-laminated sandstone to the trough cross-bedded sandstones indicate wanning flood stage followed by another episode of traction transport.

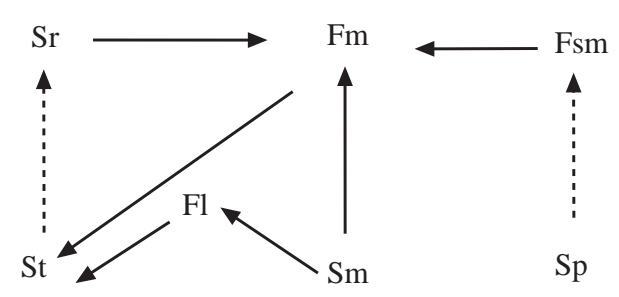

(a)

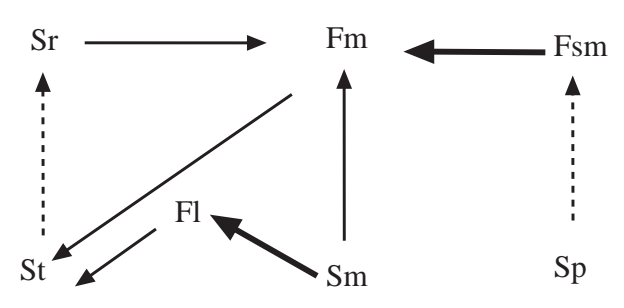

(b)

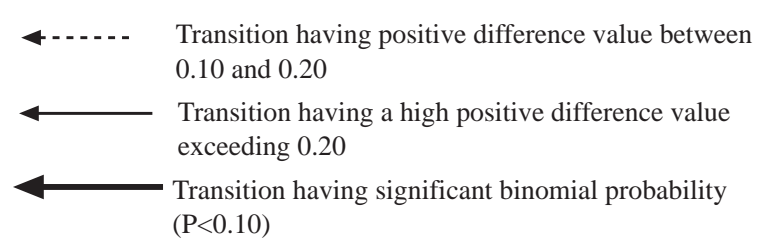

Fig. 6 Facies relationship diagram (FRD) of the Lower Siwaliks: (a) FRD showing transition that occurs commonly than random, and (b) Simplified FRD showing transition that occurs commonly and significantly (at $10 \%$ significanc level) than random.

\section{P lanar C ross-bedded Sandstone, Sp}

Sandstones with planar cross bedding are distributed in the Lower Siwaliks. Planar cross-bedded sandstones are generally thick bedded, fine-grained and greenish grey to light grey (Fig. 3). Some beds are calcareous. Vertically, $\mathrm{Sp}$ facies is associated with the $\mathrm{Sr}, \mathrm{Fm}$, Fsm facies. Facies $\mathrm{Sp}$ associated into $\mathrm{Sr}$, Fm, Fsm having positive value which occurred more frequently in the Lower Siwaliks. Sp facies is negligible in the Middle Siwaliks of the study area. Sp is formed as a results of migration of 2-D dunes. The foreset is nearly angle of repose $\left(15-30^{\circ}\right)$ with sharp, angular, upper and lower terminations indicating avalanching of sandstone in forests. Presence of 5-6 m thick Sp overlain by Fsm and $\mathrm{Fm}$ facies indicate lateral accretion of a fine-grained meandering system.

\section{$\mathrm{M}$ assive Sandstone, $\mathrm{Sm}$}

Massive sandstones are distributed in the Lower and the Middle Siwaliks of the study area. Vertically, Sm facies is well associated with the Fm facies and has positive value which occurred more frequently in the Middle Siwaliks. Facies Sm to St shows negative value of difference matrix and occurrs less frequently. In the Lower Siwaliks (Fig. 3), Sm to Fm has positive difference matrix which shows well transition. Massive sandstone dominates the Jyamire Khola section and shows grading or faint lamination. This types of facies are produced by sediment gravity flows.

\section{R ipple C ross-lam inated Sandstone, Sr}

Rippled cross laminated sandstone facies are dominant in the Middle Siwaliks as well as in the Lower Siwaliks of the study area. Wave lengths of the ripples vary from $0.25 \mathrm{~m}$ to $0.4 \mathrm{~m}$. Ripples are produced in medium-to fine-grained sandstone which are very sensitive to change in flow velocity and sediment supply. Vertically, $\mathrm{Sr}$ facies is well associated with Fm facies. Sr facies more frequently forms transition towards Fm, and follows from St facies. In the Middle Siwaliks, Sr transitions into Gmm, but does not significantly follow other facies. Ripple marks are present as undulation as non-cohesive surface (Fig. 8). They are produced as a results of interaction of waves or currents on a sediments surface. This types of facies association of St, Sr and Fm indicates the low flow regime condition and the bedforms are generated on point bars 
upon subsiding of flood water, and later on migration of channel leaving $\mathrm{Sr}$ to be followed by fines, Fm.

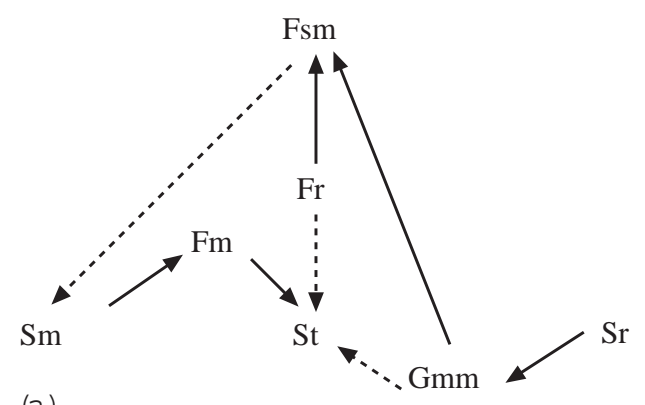

(a)

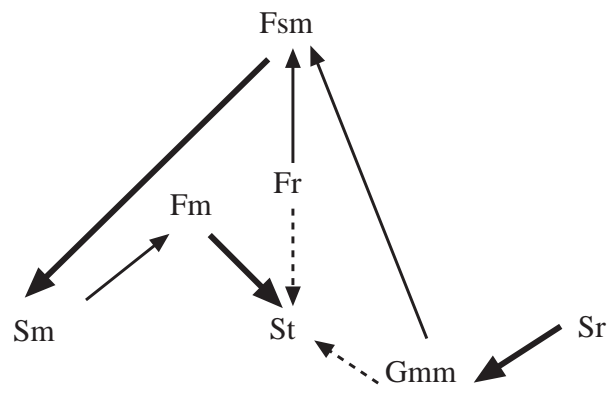

(b)

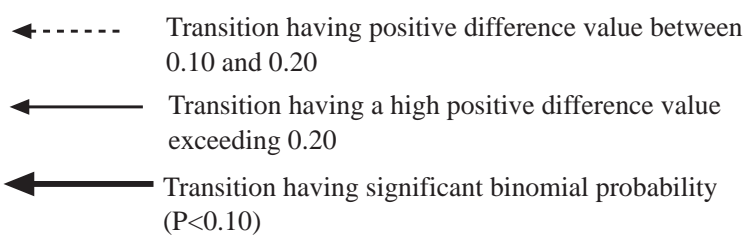

Fig. 7 Facies relationship diagram (FRD) of the Middle Siwaliks: (a) FRD showing transition that occurs commonly than random, and (b) Simplified FRD showing transition that occurs commonly and significantly (at 10\% significanc level) than random.

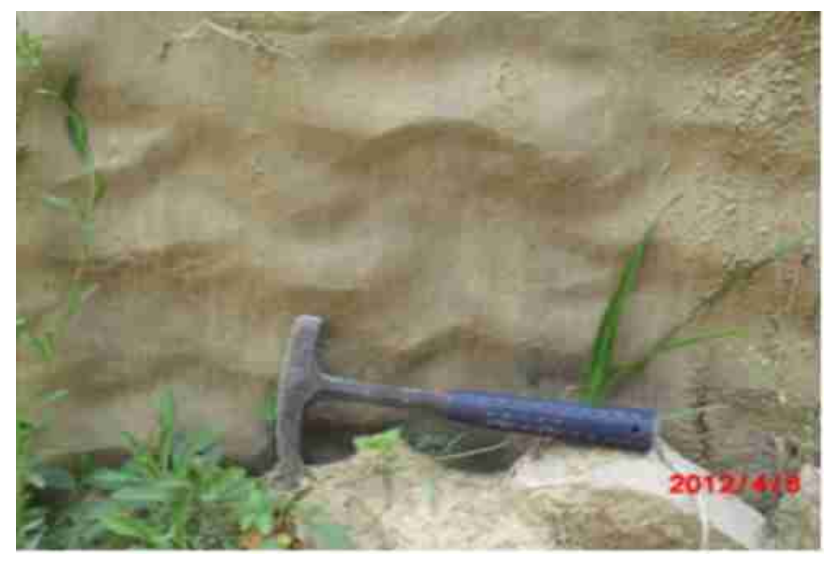

Fig. 8 Photograph showing lithofacies: Rippled-laminated, finegrained sandstone of the Lower Siwaliks exposed along the Sukaura Road section.

\section{M udrock Facies}

Mudrock facies are deposited by suspension load of rivers, because sedimentation of suspended fines need very calm environment and cannot occur in the active channel. Most of the fine particles are distributed in a floodplain area and in an abandoned channel. The thickness of the fine-grained clastic lithofacies varies from few millimeters to tens of hundreds metres in floodplains of major, suspension load stream. Some of the major fine-grained clastic lithofaices are as given below.

\section{$\mathrm{M}$ assive $\mathrm{m}$ udstone, $\mathrm{Fm}$}

Massive mudstones, Fm are often greenish grey to grey, brown, yellow, red and purple, and their thickness ranges from $0.2 \mathrm{~m}$ to $7 \mathrm{~m}$ in the Lower Siwaliks and from $0.22 \mathrm{~m}$ to $2 \mathrm{~m}$ in the Middle Siwaliks (Figs. 3 and 4). Minor association of the facies Fm with Fsm have negative matrix difference which occurred less frequently in the Middle Siwaliks. Vertically, the difference probability transition indicates significant upward transition of the Fm into St and Fsm facies. In the Lower Siwaliks, Fm facies is well associated and has transition into St, and from Sm, Sr, and Fsm. Fm transitions with $\mathrm{St}$ and $\mathrm{Sm}$ exhibit freqent occurrence. Fm facies with $\mathrm{Sr}$ and Fsm shows less probability of occurrence of these facies. It indicates that overbank, abandoned channel or mud drapes deposits frequently have association with channel trough cross bedded sand, suggesting a meandering channel environment.

$\mathrm{M}$ assive $\mathrm{Siltstone-M}$ udstone, $\mathrm{F}$.sm

Lithofacies Fsm that is massive siltstone or mudstone is dominant in the Middle and the Lower Siwaliks. In

Table 7: Facies association identified in the Samari-Sukaura Khola area.

\begin{tabular}{lllll}
\hline $\begin{array}{l}\text { Facies } \\
\text { association }\end{array}$ & $\begin{array}{l}\text { Dominant } \\
\text { lithofacies } \\
\text { types }\end{array}$ & $\begin{array}{l}\text { Minor } \\
\text { lithofacies } \\
\text { types }\end{array}$ & $\begin{array}{l}\text { Characteristic } \\
\text { architectural } \\
\text { element }\end{array}$ & Interpretation \\
\hline FA1 & $\begin{array}{l}\mathrm{St}, \mathrm{Fm}, \mathrm{Sm}, \mathrm{Sp}, \mathrm{Sr}, \\
\mathrm{Fl}\end{array}$ & $\mathrm{Fsm}$ & $\mathrm{SB}, \mathrm{FF}, \mathrm{CA}$, & $\begin{array}{l}\text { Fine-grained } \\
\text { meandering } \\
\text { river system }\end{array}$ \\
& & $\mathrm{Gmm}, \mathrm{Fr}$, & $\mathrm{SB}, \mathrm{FF}, \mathrm{LA}$, & $\begin{array}{l}\text { Sandy, mixed - } \\
\text { load } \\
\text { FA2 }\end{array}$ \\
& $\mathrm{St}, \mathrm{Fm}$, & $\mathrm{CH}, \mathrm{DA}$ & & $\begin{array}{l}\text { meandering } \\
\text { river system }\end{array}$ \\
& & & &
\end{tabular}


the Lower Siwaliks, the difference probability transition indicates upward transition of the Fsm into $\mathrm{St}, \mathrm{Sm}, \mathrm{Sr}$, Sp, Fm. Facies transitions from Fsm into Sm, Sp, and Fm have occurred more significantly compared to that of the Fsm to St and Sr. Transitions from Fsm to Sm and Fm have occurred more frequently in the Middle Siwaliks. Lithofacies Fsm represents silty and muddy deposits of floodplain located distally relative to the clastic sources such as the channel, and such facies were frequently produced by viscous flow to traction flow of the channel.

\section{M assive R ootB ed/B ioturbated M udstone, F r}

Lithofacies Fr represents massive, root bed, bioturbated mudstone formed in vegetated floodplains. This types of lithofacies is minor in the study area. Vertically, Fr facies is well associated with St and Fsm facies. Facies transitions from Fr into St and Fsm have are significant and are dominant only in the Middle Siwaliks. Fr and its transitions reflect long duration of exposure of floodplains, animal activities and vegetative growth, which were followed by the flooded channels.

\section{Lam inated Siltstone-M udstone, F 1}

$\mathrm{Fl}$ is the laminated siltstone or mudstone. It is dominant in the Lower Siwaliks, where thickness of this facies varies from $0.20 \mathrm{~m}$ to $7 \mathrm{~m}$. Vertically, Fl facies is significantly transitioned into $\mathrm{St}$, and transitioned from Sm (Fig. 6 and Table 2). This types of lithofacies represents deposition from suspension and weak traction currents, and indicates overbank, abandoned channel, or wanning flood deposits.

\section{FA C I S A SSEM BLA GE AND}

\section{DEPOSIT IONAL ENV RONM ENTS}

Two major facies assemblages have been recognized on the basis of lithology, assemblage of the sedimentary structures and sediment body architectures, and are summarized in the Table 7. Representative facies examples were taken from the prepared columnar section $(0 \mathrm{~m}$ to $1700 \mathrm{~m}$ ). The facies associations and the deposition process that produced directly related to the fluvial style which can be categorized into two broad assemblages, i.e, FA1 and FA2.

\section{Facies A ssem blage FA 1}

FA1 is facies assemblage of the trough cross-bedded, medium- to fine-grained sandstone interbedded with greenish grey to yellowish red purple, spheroidally weathered mudstone, ripple cross-laminated, fine-grained sandstone, greenish grey mudstone and siltstone. Sometimes planar cross-bedded sandstones are recognized in the Lower Siwaliks. Thickness of sandstones varies from 1.5 to $7 \mathrm{~m}$ whereas thickness of the mudstone ranges from 0.30 to $6.5 \mathrm{~m}$. Proportion of the fine sediments i.e siltstone, mudstone, fine-grained sandstone are dominant in the Lower Siwaliks. Some architectural elements i.e $\mathrm{SB}, \mathrm{FF}, \mathrm{LA}, \mathrm{CH}$ are recognized and classified as the product of the fine-grained meandering river system (Fig. 9). The overall geometry is similar to the modal 7 Miall (1985), but differ from the distribution of the fine-grained sediment load (fine sand, silt, mud).

FA1 facies association is direct product of the finegrained meandering river system. This facies association is nearly similar to the FA2 but due to the absence of gravely bed and pebbly 'salt and pepper' sandstone, it differs significantly. Trough cross-bedded, planar crossbedded and rippled laminated fine-grained sandstone are interbedded with greenish grey to red purple mudstone and siltstone which suggest that mudstone were formed on the floodplain well exposed for long time preserving ancient animals burrow. Rippled sandstone beds interbedded with the mudstones indicates that these beds were produced by floods and crevasse splaying. Lateral accreted sandstone beds, and predominent mudstone and siltstone suggest that fine-grained meandering river system prevailed during the time of deposition of the Lower Siwalik sediments.

\section{F acies A ssem blage FA 2}

FA2 is mainly characterized by very thick to thick, trough cross-bedded, medium- to fine-grained sandstone interbedded with pebbly sandstone and matrix-supported conglomerate. FA2 is also associated with spheroidally weathered to bioturbated, greenish grey mudstone. Pebbly sandstone and conglomerate beds show lateral accretion channel deposit or sometimes viscous flow deposit. Thickness of the sandstone beds are generally $2 \mathrm{~m}$ to 12 $\mathrm{m}$ whereas thickness of the mudstone beds are only 0.70 to $3.5 \mathrm{~m}$ in the fining upward cycles. Bioturbated-greenish grey mudstone is exposed on the floodplains. Mature 


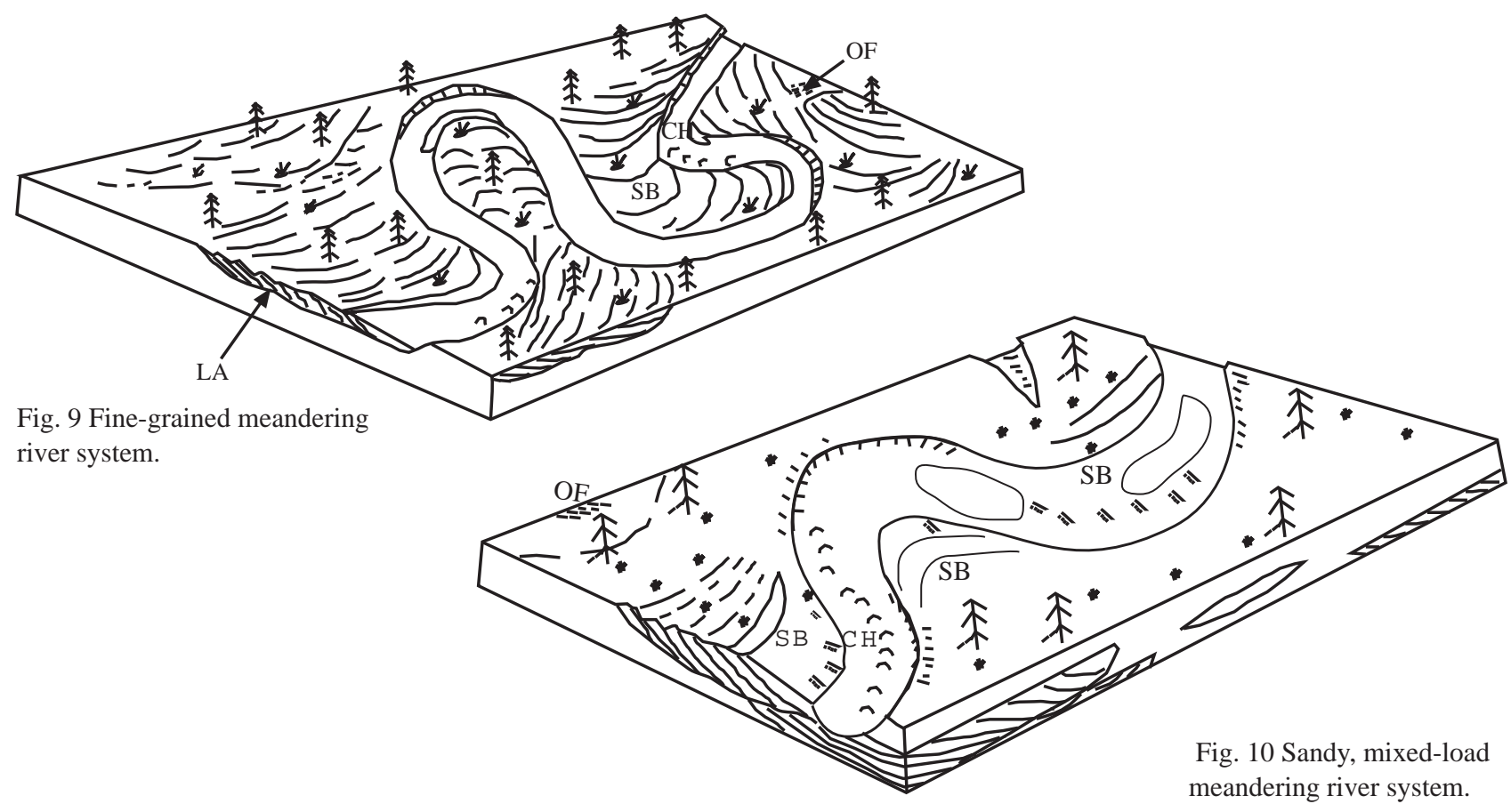

paleosols are not seen and it means episodic flood event had occurred more frequently. Thickness of the matrixsupported, conglomerate beds are approaches to $3 \mathrm{~m}$, and its thickness increases laterally in the Jyamire Khola section. In Sukaura Road section, sandy point bar accretionary face with simple geometry, well developed foreset cross-bedding, abandoned channel and crevasse splays are common. From the detail facies analysis, SB, FF, LA, DA and $\mathrm{CH}$ architectural elements were recognized. These all architectural elements can be categorized as the facies assemblage FA2. FA2 is interpreted as a product of the sandy, mixed-load meandering river system (Fig. 10). This model resembles with the model 6: classic sandy, mixed-load meandering river system of Miall (1985).

FA2 is the direct product of the sandy, mixed-load meandering river system which contains almost mediumto fine -grained, 'salt and pepper' sandstone with pebbly sandstone and also laterally extended conglomerate bed as a channel lag deposit. Succession of this pebbly sandstone to finer particles or mudstone at the top suggest that fining upward sequence assigned to a sandy, mixed load-meandering river. Pebbly 'salt and pepper' sandstone suggests that sediments of the Middle Siwaliks were derived from the source, where especially biotite percent is increased due the activation of the thrust system to unroof the Higher Himalaya, which began to uplift and most of the sediments were derived from the Higher Himalaya during the deposition of the Middle Siwaliks rock units. Greenish grey to purple, bioturbated mudstone suggests long term exposure of the floodplain. Some massive structureless sandstone were formed by sediments gravity flow or flood flow and crevasse splay sediments deposits.

\section{CONCLUSIONS}

The succession of the Siwaliks in the southern portion of the MBT has been mapped out in 1:25,000 scale and has been studied for its depositional environment.

(1) Depending on lithofacies assemblage and facies analysis the two broad facies assemblages FA1 and FA2 have been distinguished respectively for the Lower Siwaliks and the Middle Siwaliks separated in the Sukaura Road section by the Karki Khola Thrust.

(2) The lithofacies of the Lower Siwaliks are represented by fine-grained sandstone and subequal proportion of mudrock. The lithofacies of the Middle Siwaliks are charachterized by 'salt and pepper' sandstones and occasional presence of gravelly beds.

(3) FA1 contains SB, FF, LA, LS, CH architectural elements interpreted as product of the fine-grained meandering river system. FA2 contains SB, FF, LA, DA, 
$\mathrm{CH}$ architectural elements interpreted as product of sandy, mixed-load meandering river system.

\section{ACKNOW LEDGEM ENTS}

Authors thank University Grant Commission for financial support for this study of M. Sc. dissertation of the first author. Authors are also thankful to Central Department of Geology for providing field accessories and laboratory facilities. Authors thank Laxman Subedi for assistance during graphic logging and mapping.

\section{REFERENCES}

Auden, J.B., 1935.Traverses in the Himalayan, Rec. Geol. Surv. India 69(2), pp. 123-167.

Chaudhari, R.S., and Gill, G.T.S., (1981), Heavy Mineral assemblage of the Siwalik Group of Nepal Himalaya, Jourl.Geol. Soc. India, 22, pp. 220-226.

Chaudhri, R.S. (1982). Provenance of the Siwalik sediments of Nepal Himalaya. Contemporary Geolscientific Reserches in Himalaya, Vol. 2, pp. 85-90.

Critelli, S. and Ingersoll, R.V. (1994). Sandstone petrology and provenance of the Siwalik Group (northwest Pakistan and western-southeastern Nepal). Journal of Sedimentary Research, Vol. A64, pp. 815-823.

DeCelles, P.G., Gehrels, G.E., Quade, J., Ojha, T.P., Kapp, P.A. and Upreti, B.N. (1998). Neogene foreland basin deposits, erosional unroofing, and the kinematic history of the Himalayan fold-thrust belt, western Nepal. Geological Society of America Bulletin, Vol. 110, No. 1, pp. 2-21. http://dx.doi.org/10.1130/00167606 (1998) $110<0002$ : NFBDEU>2.3.CO;2

Gautam, P. and Rösler, W. (1999). Depositional chronology and fabric of Siwalik group sediments in Central Nepal from magnetostratigraphy and magnetic anisotropy. Journal of Asian Earth Sciences, Vol. 17, pp. 659-682. http://dx.doi.org/10.1016/S1367-9120(99)00021-8

Harper, C.W., Jr., 1984. Improved method of facies sequence analysis, in Walker, R.G., ed., Facies models, 2nd ed.: Geo-science Canada Reprint Series 1, pp. 11-13.

Kimura, K., 1995. Late Quaternary Morphotectonics of the Hetauda dun, Nepal sub- Himalaya . Jour.nepal Geol. Soc., v. 11 (special issue), pp. 225-235.

Kizaki, K., 1994. An Outline of Himalayan Upheaval. Jagadamba, Kathmandu, 127 p.

Miall. A.D., 1985. Architectural-element analysis: a new method of facies analysis applied to fluvial deposits. Earth Sci. Rev. 22, pp. 261-308. http://dx.doi.org/10.1016/0012-8252(85)90001-7
Miall. A.D., 1996. The Geology of Fluvial deposits, Sedimentary Facies, Basin Analysis and Petroleum Geology. Springer, Berlin, 582 pp.

Miall, A.D., 1978. Lithofacies types and vertical profile models in braided river deposit: a summary. In: Miall A.D. (Ed.), Fluvial Sedimentology. Can. Soc. Pet. Geol. Mem. 5, pp. 597-904.

Nakayama, K. and Ulak, P.D., 1999. Evolution of fluvial style in the Siwaliks Group in the foothills of the Nepal Himalaya, Jour. Sedim. Geo., v. 152, 205-224. http://dx.doi.org/10.1016/S0037-0738(99)00012-3

Petroleum exploration promotion project, 2002. Geological map of Sub Himalaya, central Nepal in 1:63000 scale. Department of Mines and Geology. Lainchaur, Kathmandu, Nepal.

Sah, R.B., Ulak, P.D., Gajurel, A.P., and Rimal, L.N., 1994. Lithostratigraghy of Siwalik Sediments of AmlekhganjHetauda area, Sub- Himalaya of Nepal. Him. Geo.,v. 15 , pp. 37-38.

Selley, R.C., 1979. Dipmeter and log motifs in North sea sub marin-fan sands: American Association of Petroleum Geologists Bulletin, v. 63, pp. 905-917.

Tamrakar, N. K. (1998). Some diagenetic characteristics of arenites from the Siwaliks, Surai Khola area, Mid Western Nepal. Bull. Dept. Geol., Tribhuvan University, Vol. 6, pp. 89-98.

Tamrakar, N.K., 2004. Microfabrics of the Siwalik Group Sandstones, Central Nepal Sub-Himalaya: Clues to Postdepositioanl Changes. Boletin de Geologia, v. 26, n. 43, pp. 39-51.

Tamrakar, N.K. and Khakurel, D., 2012. Lithologic and morphometric characteristics of the Chure River Basin, Central Nepal. Bull. Dept. Geol., Tribhuvan University, $\mathrm{Nepa} 1, \quad \mathrm{v} .15, \quad \mathrm{p}$. $35-48$. http://dx.doi.org/10.3126/bdg.v15i0.7416

Tamrakar, N.K., Yokota S., Shrestha, S.D., 2000. Petrography of the Siwalik sandstones, Amlekhganj-Suparitar area, central Nepal Himalaya. Jourl. Nepal Geol. Soc., v. 28, pp. 41-56.

Tokuoka, T., 1992. The Churai (Siwalik) Group in West Central Nepal. Bull Dept. Geol., Tribhuvan University, Nepal, pp 75-88.

Tokuoka. T., Takayasu, K., Yoshida, M., Hisatomi, K., 1986. The Churia (Siwalik) Group in the Western part of the Arun Khola area, West Central Nepal. Mem. Fac. Shim. Univ. 22, pp. 131-143.

Ulak, P.D., and Nakayama, K., 1998. Lithostratigraphy and evolution of fluvial style of the Siwalik Group in the Hetauda-Bakiya Khola area, central Nepal. Bull. Dept. Geo., Tribhuvan Univ., Kathmandu Nepal, v. 6, pp. 1-14.

Ulak, P.D., 2002. Paleohydrology of the Siwalik Group along the Bakiya Khola section central Nepal Himalaya, Journal of Nepal Geological society. v. 256, pp. 49-58. 